\title{
Jan Jakub Rousseau irracjonalny buntownik
}

\section{Wprowadzenie}

Analizując dzieje myśli ludzkiej, można stwierdzić, że poglądy niektórych myślicieli nie przemijają i nie tracą na znaczeniu. Przeciwnie, stają się coraz bardziej aktualne i są odkrywane przez kolejne pokolenia. Dotyczy to rozmaitych idei i kierunków filozoficznych powstających zarówno w starożytności, jak i obejmujących nowożytność. Zdecydowanie taki właśnie charakter mają poglądy Jana Jakuba Rousseau (1712-1778), które można interpretować wciąż na nowo, $\mathrm{z}$ jednej strony poddając je krytyce, $\mathrm{z}$ drugiej strony wciąż nimi się inspirować. Na to, że „doktryna społeczna Rousseau jest zbyt złożona, zniuansowana i wielowątkowa, aby poddawała się tylko jednorodnej interpretacji" — zwrócił szczególną uwagę Marek Blaszke1. Według niego jej nieprzeciętność polegać ma na wielorakich niedookreśleniach, zawieszających wypowiedzenie do końca rzuconych myśli. Oceniając z kolei metodę stosowaną przez Rousseau, Andrzej Burda uważa, że od samego początku mieściła się ona w ramach założeń swojej epoki, przy czym za Gieorgijem Plechanowem dostrzegał jednak jej wyższość, polegającą na głoszeniu tezy obalającej wszechmoc rozumu i jego osiągnięcia odnośnie do kształtowania się i rozwoju rzeczywistości społecznej². Efektem

${ }^{1}$ M. Blaszke: Umowa spoleczna J.J. Rousseau - polityka i racjonalność. „Archiwum Historii Filozofii i Myśli Społecznej” 1987, T. 32, s. 68.

2 A. Burda: Metoda i ogólny charakter doktryny politycznej J.J. Rousseau. Lublin 1954, s. 12 i 32 . 
tego miał być russowski ukłon w stronę irracjonalizmu, który jakże wyraźnie widoczny jest w jego filozofii. Irracjonalizm Rousseau wiąże się bowiem bezpośrednio z jego przewodnim hasłem ,powrotu do natury”, które do dziś — jak się wydaje - tętni nie tylko intelektualnym, ale także emocjonalnym życiem. Konieczność ustąpienia miejsca, zajmowanego dotąd przez rozum, czynnikom pozarozumowym okazała się jedyną, według niego, szansą takiego właśnie powrotu i życia zgodnego z naturą. Rozum będący bowiem źródłem poznawania świata przez człowieka, odrzucając jednak całkowicie bądź umniejszając znaczenie innych źródeł poznawczych, w które wyposażyła nas natura, prowadzi w konsekwencji do nieszczęścia. Dlatego wszelkie aprioryczne przyznawanie ludzkiemu rozumowi nieomylności dla jednych związane było ze złem ludzkiej natury i grzechem pychy, dla innych stanie się podstawą alienacji człowieka ${ }^{3}$. Ta ostatnia staje się u Rousseau wyrazem rozdźwięku między istotą a istnieniem człowieka, między jego powołaniem i działaniem ${ }^{4}$. Zdaniem Bronisława Baczki sytuacja alienacyjna powstaje zawsze w toku współdziałania osobników, a ich wzajemna zależność powoduje, że jednostka zaczyna działać nie ze względu na samą siebie, lecz ze względu na to, jaką jest w oczach innych ${ }^{5}$.

Krytykując jedynie stanowiska sprzeczne z własnymi ustaleniami, rozum podważa właściwie swoją istotę. Stając się bezkrytycznym wobec samego siebie, rozum może być niebezpieczny, prowadząc w sensie logicznym do błędów, tworząc najczęściej sofizmaty bądź paradoksy, które z kolei Jan Jakub Rousseau określił jako antynomie. Doceniając poglądy Rousseau, Immanuel Kant (1724-1804) w swojej Krytyce czystego rozumu przedstawił najważniejsze, jego zdaniem, antynomie, które w związku z agnostycyzmem pomogły uznać klasyczną metafizykę jedynie za naukę spekulatywną ${ }^{6}$. Filozofia Rousseau jest przy tym o tyle wyjątkowa, że nie opierała się jak dotychczasowe filozofie na metafizyce jako tzw. filozofii pierwszej, ale za najważniejsze stawiała sobie problemy społeczne, które zamierzała jednak rozwiązać. W ten sposób Jana Jakuba Rousseau powinno się od początku jego twórczości uznawać za praktyka, a nie jedynie teoretyka, o wiele bardziej za artystę niż za filozofa, który rozwijał własną i oryginalną myśl w ramach działów filozofii, które dziś określamy mianem filozofii społecznej, filozofii prawa i filozofii polityki. W związku z tym dał się

${ }^{3}$ Jana Jakuba Rousseau i jego poglądy nie tylko można, ale nawet trzeba rozpatrywać w wielu kontekstach pozwalających na swobodną ich interpretację prowadzącą często do krańcowo odmiennych ocen i wniosków badawczych. Nie najważniejsze jest przy tym to, czy jest on aprobowany czy krytykowany, lecz to, że tak szeroko i rozbieżnie jest od początku swojej twórczości ujmowany; zob. M. Zmierczak: Jan Jakub Rousseau - rzecznik totalitaryzmu czy liberalnej demokracji?. „Czasopismo Prawno-Historyczne” 1989, T. 41, z. 2, s. 1-16.

${ }^{4}$ B. Baczko: Rousseau: samotność $i$ wspólnota. Warszawa 1964, s. 47.

${ }^{5}$ Ibidem, s. 51.

${ }^{6}$ Por. I. Kant: Krytyka czystego rozumu. Tłum. R. Ingarden. T. 2. Warszawa 1957, s. 164 i nast. 
on poznać w epoce Oświecenia jako znany już wówczas twórca oryginalnej doktryny społecznej, politycznej i ekonomicznej, w tym przede wszystkim: teorii umowy społecznej ${ }^{7}$, dalej naturalistycznej koncepcji wychowania ${ }^{8}$ czy nawet jako językoznawca'. Jego poglądy uznaje się często za bezkompromisowe i kontrowersyjne, gdyż do dziś mają albo swoich entuzjastów, albo krytyków i zagorzałych przeciwników. Niemniej jednak 240 lat od jego śmierci poglądy te pozostają wciąż aktualne, a nawet stają się coraz bardziej interesujące, zwłaszcza dla tych, którzy czują się zagubieni w świecie zdominowanym przez rozwijającą się cywilizację technologiczną, jednocześnie oddalającą się od natury, czyli tak naprawdę pozbawiającą nas możliwości osiągnięcia życia szczęśliwego. Życia, którego nie da się zorganizować tak jak zakłada rozum w nieodwracalnym dla niego procesie cywilizacyjnym, jedynie pędząc w przyszłość oznaczającą kres ludzkości i utratę człowieczeństwa ${ }^{10}$.

\section{Rousseau - mistrz paradoksów}

Jana Jakuba Rousseau jako człowieka paradoksów, przedstawiał chociażby jeden $\mathrm{z}$ największych badaczy jego życia, twórczości i światopoglądu - Bronisław Baczko. Według niego paradoksy Rousseau wiązały się zarówno z codziennym życiem i działalnością szwajcarskiego filozofa, jak również przenikały jego twórczość i poglądy. Były bowiem wynikiem wewnętrznego konfliktu narastającego pod wpływem napięcia między ideałami, w które wierzył, a rzeczywistością, z którą się nie zgadzał, a zatem którą krytykowa ${ }^{11}$. Konflikt ten doprowadził on do postaci radykalnej, nadając mu sens zarówno osobisty, jak i ogólnoludzki ${ }^{12}$. To właśnie $\mathrm{z}$ niego wyłoniła się postać Rousseau jako prawdziwego buntownika, z jednej strony skłóconego ze światem, który sami sobie

${ }^{7}$ Zob. J.J. Rousseau: Umowa spoteczna. Przeł. A. Peretiatkowicz. Warszawa 1966; J.J. Rousseau: Uwagi o rzadzie polskim. Tłum. B. Baczko. Warszawa 1966.

${ }^{8}$ J.J. Rousseau: Wybór tekstów pedagogicznych. Oprac. H. Pohoska. Warszawa 1949.

9 J.J. Rousseau: Szkic o pochodzeniu języków. Przeł. B. Banasiak. Kraków 2001; zob. H. Święczkowska: Pochodzenie języka wedlug Jana Jakuba Rousseau: kilka uwag na marginesie przekładu polskiego. „Idea. Studia nad rozwojem i strukturą pojęć filozoficznych” 2003, T. 15 , s. $73-82$.

${ }^{10}$ Obecnie transhumaniści obok pozytywnych aspektów rozwoju technologicznego, wskazują coraz częściej na związane z nim zagrożenia dla dotychczasowego życia człowieka; zob. K. Kuźmicz: Transhumanizm. W: Edukacja na rozdrożu. Red. M. Szyszkowska. Białystok 2015, s. $170-186$.

${ }_{11}$ B. Baczko: Rousseau: samotność i..., s. 515.

${ }^{12}$ Por. Idem: Paradoksy russoistyczne. Wstęp do dziet wybranych J.J. Rousseau. Warszawa 1966 , s. LV. 
tworzymy - cywilizacja; z drugiej strony zauroczonego światem, który sami niszczymy - natura. Filozof perfekcyjnie „kokietuje” paradoksem w swych pismach po to, aby wyraźniej uwypuklić odmienność swojej wizji świata od poglądów powszechnie dominujących ${ }^{13}$.

W rezultacie można nawet powiedzieć, że wszystko, co wiąże się z Janem Jakubem Rousseau, zwłaszcza jego życiem i poglądami, jest pełne rozmaitych sprzeczności. Już sam fakt bycia samoukiem sprawia, że można traktować go albo jako mędrca czy geniusza, albo jako szarlatana, a nawet głupka. Sam Rousseau zdawał sobie z tego doskonale sprawę, pisząc, że „woli być człowiekiem paradoksów niż człowiekiem przesądów"14. Pierwsze są bowiem dla niego jedynie czymś nielogicznym, czego nie jest w stanie pojąć rozum, te drugie natomiast rozum sam sobie wytwarza, mimo iż ma na celu je obalać, co również możemy uznać za swoisty paradoks. W okresie uwielbienia cywilizacji i jej zdobyczy oraz kultu rozumu bronił on przecież praw uczucia i prostoty natury, jego głos tonął $\mathrm{w}$ marzeniach, gdyż nie umiał się zżyć z rzeczywistością ${ }^{15}$, tym bardziej nie mógł się z nią pogodzić. Spośród licznych paradoksów Rousseau, o których wspominał, prawdziwym jego odkryciem, zdaniem Andrzeja Waśkiewicza, jest obcość połączona $\mathrm{z}$ wyobcowaniem, stanowiąca fundamentalny problem człowieka, który nigdy nie może być u siebie, a tym samym nigdy nie może być ze sobą ${ }^{16}$. Sam Rousseau ujął to następującymi słowy: „nie istniejemy tam, gdzie jesteśmy; istniejemy tam właśnie, gdzie nas nie ma""17.

Największy jednak paradoks Jana Jakuba Rousseau dotyczy jego metody, która przypomina metodę scholastyczną, zaproponowaną przez św. Augustyna z Tagesty, a rozwijaną chociażby przez św. Anzelma z Canterbury. Tak jak od wiary, będącej aktem łaski Boga, która jest irracjonalna, poprzez racjonalnie ujmowanie jej i powrót do niej powinniśmy wiarę, a zwłaszcza jej dogmatyczne złożenia, wzmacniać ${ }^{18}$. Tak u Rousseau, my ludzie (istoty rozumne) powinniśmy wyjść od naszej racjonalności, która świadomie ustępując miejsca czynnikom irracjonalnym, zapewni nam możliwość autentycznego życia zgodnego z Naturą i jej rozumnością. Zdaniem scholastyków wiara wymagała i szukała uzasadnienia rozumowego ${ }^{19}$, a w koncepcji Rousseau to rozum szukał i wymagał uzasadnienia irracjonalnego. Rousseau zastanawiał się, jak rozum ludzki, ujmowany jako nasz intelekt, ma przejść do Logosu jako mądrości samej Natury, czyli kosmosu. W rezultacie doszedł do wniosku, że nie można pojąć mądrości Natury bez woli i uczuć.

\footnotetext{
${ }^{13}$ Por. ibidem, s. XVI.

14 J.J. Rousseau: Emil czyli o wychowaniu I. Przeł. W. Husarski. Wrocław 1955, s. 90.

15 W. Tatarkiewicz: Historia filozofii. T. 2: Filozofia nowożytna do roku 1830. Warszawa

16 Por. A. Waśkiewicz: Obcy z wyboru. Studium filozofii aspolecznej. Warszawa, s. 313.

17 J.J. Rousseau: Emil, czyli..., s. 75.

${ }_{18}$ Credo ut inelligam et intelligo ut credam.

${ }_{19}$ Fides Quaerens Intellectum.
} 1990, s. 150. 


$$
\begin{aligned}
& \text { Rozum } \rightarrow \text { uczucia i wola } \rightarrow \text { Natura } \\
& \text { (intelekt) } \rightarrow \text { (czynniki irracjonalne) } \rightarrow \text { (Logos) }
\end{aligned}
$$

Paradoksalność swojej osobowości podsumował, pisząc w Marzeniach samotnego wędrowca, że urodził się, aby żyć, a umierał, nie zakosztowawszy życia ${ }^{20}$. Dlatego należy zgodzić się z Markiem Blaszke, według którego częste sprzeczności w wypowiedziach Jana Jakuba Rousseau są z reguły dowodem głębszego wniknięcia w strukturę rzeczywistości, która powierzchownie wydaje się w pełni harmonijna, a dopiero pod powłoką ujawnia swoje liczne powikłania i niekoherencje ${ }^{21}$. Paradoksy w myśli Rousseau zdecydowanie wpływają na ocenę całości jego działa ${ }^{22}$. W pewnym sensie to właśnie dzięki paradoksom, z którymi nie potrafił sobie poradzić rozum, wzmacniał on irracjonalność swojego filozoficznego systemu. Ten ostatni z kolei pomógł mu wykreować światopogląd, który śmiało można określić mianem światopoglądu buntownika.

\section{Rousseau - irracjonalista i buntownik}

Właściwie całe dzieło Jana Jakuba Rousseau można uznać za irracjonalne i buntownicze. Według Bronisława Baczki jest ono „protestem i buntem przeciwko istniejącemu porządkowi rzeczy - jest wezwaniem do powrotu do samego siebie, apelem do tych sił w człowieku, które mogą taki powrót zapewnić" ${ }^{23}$. Dlatego irracjonalny światopogląd o charakterze buntowniczym Rousseau rozwijał od początku swojej twórczości i robił to metodycznie przez całe życie. Dał temu wyraz już w swojej pierwszej Rozprawie o naukach i sztukach z 1749 r., w której przedstawił jego zarys. Poddał w niej krytyce główne założenia ideologiczne epoki Oświecenia, opierającej się do tej pory na zdobyczach racjonalizmu (rozumu) i empiryzmu (zmysłów). Jego zdaniem , ,...] nasze dusze wypaczały się, w miarę jak nasze nauki i sztuki zmierzały ku doskonałości”24. Diagnozę postawioną wówczas przez Rousseau trafnie podsumował Jędrzej Morawiecki, zaznaczając, że im wyższy zachodzi rozwój cywilizacyjny, tym silniejsza następuje utrata jej duchowych podstaw ${ }^{25}$. Proces cywilizacyjny, we-

\footnotetext{
20 J.J. Rousseau: Marzenia samotnego wędrowca. Wrocław 1983, s. 17.

${ }^{21}$ Por. M. Blaszke: Umowa spoleczna..., s. 41.

22 A. Waśkiewicz: Obcy z wyboru..., s. 365.

${ }^{23}$ B. Baczko: Rousseau: samotność i..., s. 55.

${ }^{24}$ J.J. Rousseau: Rozprawa o naukach $i$ sztukach. W: Idem: Trzy rozprawy z filozofi społecznej. Wrocław-Warszawa-Kraków 1956, s. 15.

${ }^{25}$ Por. J. Morawiecki: Strach zabija róże. „Polityka” 1998, nr 39, s. 104.
} 
dług Rousseau, był jednak nieunikniony i nieodwracalny podobnie jak proces starzenia się ludzi ${ }^{26}$.

Jednakże nie zaspokoiło to jego najważniejszego celu, którym było „poznanie człowieka [...] [i] przyjrzenie mu się w jego stosunkach z innymi”"27. Z czasem „Rousseau zaczyna wierzyć w inną siłę kierującą człowiekiem, a którą możemy nazwać doświadczeniem wewnętrznym, porywem uczucia, czy też nieodpartym głosem serca" ${ }^{28}$. Szczególną uwagę na to zwróciła we Wstępie do Nowej Heloizy Ewa Rzadkowska, wskazując na jego związki z encyklopedystami, dzięki którym doceniał on zwłaszcza francuski racjonalizm i empiryzm Johna Locke'a ${ }^{29}$. W rezultacie irracjonalizm Rousseau przybiera postać buntu wobec dominacji tych dwóch kierunków filozoficznych. Ów bunt, w jego przypadku, można interpretować na wiele rozmaitych sposobów, zaczynając od popularnej wówczas na gruncie filozofii metody jako świadomego krytycyzmu, by dojść w końcu na gruncie społeczno-politycznym, czyli w działaniu do rewolucjonizmu. W tym kontekście twórczość Jana Jakuba Rousseau stała się „walką o doskonalszą formę bytowania [...], w której emocje, przejęcie się i powaga stanowiły nuty zasadnicze, a uczuciowe napięcie zamącało nawet czasem pod względem logicznym wypowiedzianą treść myślową"30.

A zatem buntowniczość poglądów i postawy życiowej pochodzącego z Genewy myśliciela polegała na krytykowaniu, podważaniu, negowaniu, ośmieszaniu, zwalczaniu, sprzeciwianiu się i niegodzeniu się na wszystko to, co sprzeczne było, jego zdaniem, z Naturą. Bunt ten przybierał również postać, którą współcześnie możemy dodatkowo określać jako obalanie mitów, stawanie w opozycji, przekraczanie granic czy podważanie dotychczasowych schematów bądź stereotypów. Badając światopogląd tego genewskiego myśliciela, można dojść do wniosku, iż odpowiada on modelowi tzw. dezintegracji pozytywnej Kazimierza Dąbrowskiego $^{31}$. Świadczyć o tym mogą słowa samego Rousseau: „Ja sam. Czuję moje serce i znam ludzi. Nie jestem podobny do żadnego z tych, których widziałem; śmiem wierzyć, iż nie jestem podobny do żadnego z istniejących. [...] Im dłużej żyłem na świecie, tym trudniej mi było dostroić się do jego tonu" ${ }^{32}$. Poza tym uważał, że nie ma na tym świecie ani bliźniego, ani istot mu podobnych, ani braci, że jest na ziemi jak na obcej planecie, strącony z tej, którą dotąd zamieszkiwał ${ }^{33}$.

${ }^{26}$ Por. J. Baszkiewicz, F. Ryszka: Historia doktryn politycznych i prawnych. Warszawa 1979, s. 253.

27 J.J. Rousseau: Nowa Heloiza. Tłum. E. Rzadkowska. Warszawa 1995, s. 103.

${ }^{28}$ Zob. E. Rzadkowska: Wstęp. W: J.J. Rousseau: Nowa Heloiza..., s. 11.

${ }^{29}$ Ibidem, s. 8-11.

${ }^{30}$ B. Orłowski: Krytyka wartości kultury u Rousseau i przed Rousseau'em. Ze studjów nad geneza i znaczeniem rozpraw konkursowych Jana Jakóba Rousseau. Poznań 1921, s. 222.

${ }_{31}$ Zob. K. Dąbrowski: Dezintegracja pozytywna. Warszawa 1979.

32 J.J. Rousseau: Wyznania I. Przeł. T. Żeleński (Boy). Warszawa 1978, s. 33 i 192.

${ }^{33}$ J.J. Rousseau: Marzenia..., s. 9. 
Był samotnikiem z wyboru, a dzięki prawdzie, w którą wierzył, z całą świadomością postanowił ujawnić ludzkie zakłamanie, wskazując mankamenty tego świata. Jeszcze dalej w ocenie Jana Jakuba Rousseau poszedł Thomas Carlyle, który stwierdził, że życie, jakie prowadził ten człowiek, popchnęło go do tak otwartej wrogości wobec świata, czyniąc przy tym z niego bohatera. „Wygnano go na poddasza paryskie, gdzie kazano mu pozostawać w towarzystwie własnych ponurych myśli i biedy, przerzucano go z deszczu pod rynnę, nie szczędzono zadraśnięć, doprowadzono do rozpaczy, aż wreszcie szał ogarnął jego serce, aż wreszcie uczuł on głęboko, że ani świat ani jego prawa nie były mu przyjacielem" ${ }^{34}$.

W ten sposób jako „pozytywnie nieprzystosowany” do świata, w którym przyszło mu żyć, Jan Jakub Rousseau stał się buntownikiem okazującym nawet wrogość. W pierwszej kolejności przeciwko wszystkiemu, co dominowało w tym świecie, zarówno jego nauce i filozofii, kulturze i sztuce oraz przeciwko zasadom, na których opierało się dotychczasowe życie społeczne ludzi. Następnie sprzeciwiał się temu, że rozumowi przyznajemy pierwszoplanową rolę nie tylko $\mathrm{w}$ procesie poznawczym, ale także $\mathrm{w}$ procesie cywilizacyjnym. Potępiał zwłaszcza to, że tak łatwo i szybko godzimy się na wyeliminowanie przez rozum innych tzn. irracjonalnych źródeł poznawczych, które według niego prowadzić nas mają do bardziej wszechstronnego rozwoju, zarówno tego indywidualnego, jak również społecznego. Wynika z tego, że swój irracjonalny bunt Rousseau nieustannie rozciągał w kierunku problemów społecznych, do powstawania których rozum się bezapelacyjnie przyczyniał, a których nie potrafił samodzielnie rozwiązać. Rousseau występował także wobec wszystkiego, co sztuczne i nienaturalne, a zarazem niemoralne i niesprawiedliwe, między innnymi przeciwko temu, że człowiek z natury rodzi się przecież wolny, a mimo to wszędzie jest w kajdanach, że przyczyną tego wszystkiego było pierwsze ogrodzenie kawałka ziemi i wskazanie, iż należy do kogoś, czyli pojawienie się własności prywatnej, że doprowadziła ona zdecydowaną większość ludzi, którzy jej nie posiadali, do biedy, że praca ludzi biednych stała się przymusem i wyzyskiem, czyniąc z nich faktycznych niewolników, i wreszcie, że ci ostatni ujmowani jako lud pozbawieni są praw politycznych i możliwości wyrażania swojej woli, którą Jan Jakub Rousseau określi ostatecznie jako wolę powszechną.

Powyższą kwestię niezwykle trafnie podsumował Lion Feuchtwanger, pisząc o tym, że filozofia Jana Jakuba Rousseau zrodziła „buntownicze myśli”, a większy od największej książki Jana Jakuba stał się jego czyn: rewolucja. „Było to jego najstraszliwsze, najwstrętniejsze i najbardziej podniosłe dzieło. Była w pełni jego tworem, miała jego rysy, była dokładnym odbiciem jego istoty i jego życia. Grzeszyła jego ogromnym błogosławionym grzechem: topiła rozsądek w powodzi

${ }^{34}$ T. Carlyle: Bohaterowie, cześć dla bohaterów i pierwiastek bohaterstwa $w$ historii: Odyn, Mahomet, Dante, Szekspir, Luter, Knox, Johnson, Rousseau, Cromwell, Napoleon. Warszawa 2010, s. 239. 
uczucia”35. To właśnie jego „na poły bełkotliwe rozumowania” jako „ewangelisty rewolucji”, dotyczące chociażby życia cywilizowanego, przyczyniły się bardzo nie tylko do „wywołania szału zupełnego i powszechnego w całej Francji”, ale także „do wzniecenia pożaru świata”, jakim okazała się rewolucja francuska z $1789 \mathrm{r}^{36}$. Niepodważalnym faktem pozostaje jednak to, że Jan Jakub Rousseau nie doczekał się jej wybuchu, w związku z czym trudno jego samego uważać za rewolucjonistę. $Z$ kolei jako buntownik $z$ wyboru i przekonań uznawany jest słusznie za jej wielkiego prekursora, to niekoniecznie już za jej propagatora. Zwłaszcza jakobiński kult jego osoby i poglądów, z jednej strony, był prawdziwy i na pewno szczery; z drugiej natomiast strony był przy tym zbyt powierzchowny i nadto ideologiczny. Choć rozumiano sens przesłania genewskiego myśliciela, to jednak nie wyczuwano go, tak jak należało to robić. Rozum, który nie ustępuje miejsca uczuciom i woli, w końcu się pomyli i popełni błąd, ,ponieważ im więcej ludzie wiedzą, tym się bardziej mylą [..."”37. Optymistyczne jest przy tym to, że Rousseau nie traci na moment nadziei i wierzy wciąż w ludzi, w mocy których jest $\mathrm{z}$ tego całego zła wydobyć jednak dobro ${ }^{38}$. Ów powrót do dobra zaproponowany przez Jana Jakuba Rousseau związany jest właśnie z buntem przeciwko historii, a zwłaszcza ówczesnej sytuacji historycznej. Jean Starobinski dodaje przy tym, że ,jeśli myśl Rousseau mamy uznać za rewolucyjną, to trzeba natychmiast dodać, że jest ona taka w imię odwiecznej natury ludzkiej, a nie w imię historycznego postępu"39.

\section{Zalety irracjonalizmu}

Rousseau, choć nie negował zupełnie rozumu i jego dotychczasowych osiągnięć, zwłaszcza tych na polu nauki, to jednak zawsze podważał jego pierwszoplanową i dominującą pozycję, z którą się nie zgadzał. „Mimo niechęci do cywilizacji, sztuk, nauk, filozofii [...] nie żądał wcale, by spalić biblioteki, zniszczyć własność i wrócić do lasu, by żyć z niedźwiedziami”" ${ }^{40}$. Jednakże, w ogólnym rozrachunku, to właśnie rozum uznał on odpowiedzialnym za moralne zło i niesprawiedliwość społeczną, które wynikały z bezwzględnego kierowania się nim,

${ }^{35}$ L. Feuchtwanger: Mądrość glupca albo śmierć i apoteoza Jana Jakuba Rousseau. Tłum. J. Frühling. Warszawa 1959, s. 433.

${ }^{36}$ Por. T. Carlyle: Bohaterowie, cześć dla bohaterów..., s. 239.

37 J.J. Rousseau: Emil czyli..., s. 256.

${ }^{38}$ Por. B. Suchodolski: Rozwój nowożytnej filozofii człowieka. Warszawa 1967, s. 700.

39 J. Starobinski: Jean-Jacques Rousseau. Przejrzystość i przeszkoda oraz siedem esejów o Rousseau. Przeł. J. Wojcieszak. Warszawa 2000, s. 32.

${ }^{40}$ J. Baszkiewicz, F. Ryszka: Historia doktryn politycznych..., s. 253. 
z pominięciem czynników pozarozumowych, przede wszystkim uczuć i woli. Uznał on, że dla prawidłowego i harmonijnego rozwoju człowieka niezbędne jest korzystanie ze wszystkich źródeł poznawczych, które powinno się harmonijnie rozwijać, żadnego nie pomijając i kosztem innych nie zaniedbując. Owe irracjonalne źródła poznawcze są w koncepcji szwajcarskiego filozofa najbardziej naturalne i pierwotne. Na pierwszym miejscu wśród nich cenił wolę, zwłaszcza za jej naturalną siłę życia. Wola życia, podobnie jak jego wola powszechna, jest najwyższym dobrem, prawem i zasadą bytu, zarówno w sensie metafizycznym, jak i w sensie etycznym, społecznym, politycznym, prawnym oraz ekonomicznym. Stanowi ona podstawową siłę naturalną przenikającą wszelkie jestestwo. Wola życia to nieustająca chęć dążenia do szczęścia. Dlatego naturalne i moralne jest wszystko, co życiu sprzyja, a więc dbanie o nie, pielęgnowanie go, dzielenie się nim oraz jego ochrona. Wszystko, co żyje, chce zatem żyć i to jak najdłużej $\mathrm{w}$ sensie biologicznym, i jak najlepiej w sensie moralnym. Wola w rozumieniu Rousseau jest zatem pierwotnym, wiecznym i niezmiennym nakazem samej natury i źródłem jej praw. Podstawowym warunkiem osiągnięcia szczęścia jest zatem kierowanie się zawsze i wszędzie właśnie wolą; żyjąc zgodnie z naturą, czyli zachowując jako najważniejsze takie wartości jak: równość, wolność i braterstwo. Tylko dzięki nim zarówno każdy człowiek — indywidualnie, jak i ludzkość mogą być szczęśliwi, tak jak to miało miejsce $\mathrm{w}$ stanie natury. W ten sposób koncepcja Rousseau jawi się nie tylko jako klasyczny egalitaryzm związany z jego teorią prawa natury, ale także swego rodzaju liberalizm i solidaryzm. Jest egalitaryzmem, gdyż na pierwszym miejscu stawia między ludźmi równość, liberalizmem, gdyż natura obdarzyła nas wszystkich, także wolnością. Z tym, że oryginalność jego podejścia do wolności sprowadza się do tego, że o wolności jednostki w ramach zorganizowanej społeczności możemy mówić jedynie wtedy, gdy ściśle i nierozerwanie pozostanie ona złączona $\mathrm{z}$ równością. Zdaniem Rousseau, tam bowiem, gdzie nie ma równości między ludźmi bądź tam gdzie nierówności społeczne się pogłębiają — wolność nie istnieje albo stopniowo zanika. W rezultacie Jan Jakub Rousseau, w przeciwieństwie do klasycznych przedstawicieli liberalizmu, nie traktował wolności jako wartości samoistnej i jedynie zindywidualizowanej oraz odrzucał własność prywatną, która nie tylko nie pochodziła z prawa natury, ale z prawem tym była według niego całkowicie sprzeczna. W tym kontekście wolność dla Rousseau stanowi przede wszystkim ,prawo do indywidualnego buntu, dla którego jedyną, ale i wystarczającą sankcją jest wewnętrzny głos sumienia" ${ }^{\text {"41 }}$. Uznając go w końcu za prekursora solidaryzmu społecznego, należy zaznaczyć, że tylko wolnych i równych sobie ludzi można uznać za prawdziwych braci, a w taki właśnie sposób wszystkich ludzi traktuje jedynie natura.

Kolejnym równie ważnym naturalnym źródłem poznawczym człowieka, według Jana Jakuba Rousseau, są uczucia, ponieważ: „to w sercu człowieka żyje

${ }^{41}$ B. Baczko: Paradoksy russoistyczne..., s. L. 
piękno natury; ażeby je wiedzieć, trzeba je czuć"^2. Uczucia i namiętności to coś, co dziecko odczuwa i wyraża, zanim zrozumie, że je posiada i może nad nimi panować. W ten sposób wychowywanie i przynależne mu emocje poprzedzają jednak nauczanie związane z myśleniem. Zdaniem Rousseau: ,pierwsze wychowanie powinno być zatem czysto negatywne. Polega ono nie na nauczaniu cnoty lub prawdy, lecz na strzeżeniu serca przed występkiem i umysłu przed błędem. [...] Ćwicz jego ciało, jego narządy, jego zmysły, jego siły, ale duszę jego utrzymuj w próżnowaniu, póki to będzie możliwe"43. Ostrzega on jednak przed tym, że „uczucia, które rodzą się, zanim umysł może je osądzić, są niebezpieczne"44. Aby uniknąć tego zagrożenia, Rousseau uznaje za najważniejsze bycie dla ludzi, z którymi się żyje ${ }^{45}$. Prawidłowe jest, jego zdaniem, to, że dziecko kocha matkę, zanim dowie się, że tak właśnie być powinno ${ }^{46}$. Wychowanie, które propaguje, jest zgodne $\mathrm{z}$ naturą $\mathrm{i}$ jej porządkiem, gdyż wiąże się z empatią i szacunkiem dla drugiego człowieka, zwłaszcza tego, który jest w gorszej sytuacji od nas. Przykładowo wymaga on zawsze od szczęśliwszego, czyli: wolnego, zdrowego, bogatego, silnego, sytego, zdolnego, przystojnego itp. przede wszystkim litości dla: zniewolonego, chorego, biednego, słabego, głodnego, nieutalentowanego czy brzydkiego. Według samego Rousseau istotę takiego wychowania można streścić w trzech ścisłych, jasnych i łatwo zrozumiałych maksymach, które przedstawił w IV księdze Emila, czyli o wychowaniu. „Maksyma pierwsza: Nie leży w naturze ludzkiego serca, by stawiać się w położeniu ludzi szczęśliwszych od nas, ale tych tylko, którzy są bardziej od nas godni współczucia. [...] Maksyma druga: Litujemy się nad tymi tylko boleściami bliźnich, od których sami nie czujemy się wolni. [...] Maksyma trzecia: Litość wzbudzana cierpieniem bliźniego nie mierzy się ilością tego cierpienia, ale uczuciem, którym darzymy cierpiącego" ${ }^{\text {"47 }}$.

A zatem należy uznać, że zarówno dla prawidłowego rozwoju jednostki, jak i społeczeństwa, sfera emocjonalno-wolitywna jest ważniejsza od tej, która stanowi rezultat poznania zmysłowego i rozumowego. Według Rousseau nawet ustrój ma być lepszy i trwalszy, ale dopiero wtedy, gdy prawo będzie rządziło sercami obywateli ${ }^{48}$. Empiryzm i racjonalizm są jednak niezbędne do rozwoju nauk i sztuk, które Rousseau przecież od początku tworzenia swojej koncepcji filozoficznej krytykował. Wyraził to przecież w swojej słynnej Rozprawie o naukach i sztukach, w której postawił kontrowersyjną i wbrew dominującej w czasach Oświecenia tezę, że racjonalny rozwój nauk i sztuk nie czyni ludzi lepszymi, wręcz przeciwnie prowadzi nas w konsekwencji do złego. Każdy człowiek posłu-

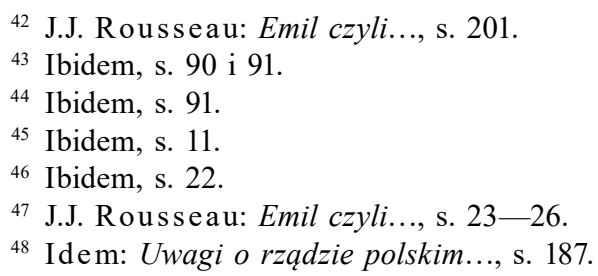


gujący się rozumem, przy jednoczesnym zagłuszaniu głosu serca i sprzeciwianiu się sile woli odpowiedzialny jest za zło. Naturalnym bowiem zadaniem rozumu było przecież uczenie nas rozpoznawania dobra i zła ${ }^{49}$. Odtrącając jednak nasze uczucia i wolę, pozbawiliśmy praktycznie rozum możliwości dokonywania właściwych wyborów moralnych. Rousseau przedstawił własną koncepcję teodycei usprawiedliwiającą Boga i jego Opatrzność, którym jest wdzięczny przede wszystkim za to, że obdarzył nas w zasadzie naturą doskonałą, nadając naszym czynom charakter moralny, czym uszlachetnił je i dał nam prawo do cnoty $^{50}$. W rezultacie dziękuje on za wolność, która daje między innymi możliwości posługiwania się nie tylko rozumem, lecz korzystania i rozwijania w harmonijny sposób wszystkich naszych zdolności poznawczych. Jednocześnie w wymownych słowach ostrzega nas przed nami samymi: „Człowieku, nie szukaj zatem twórcy zła - twoim jest ono dziełem! Są tylko dwa rodzaje zła: zło, które ty czynisz, i zło które ty cierpisz - jedno i drugie mają źródło w tobie" ${ }^{51}$.

W związku z tym rozum ze swoimi osiągnięciami w ramach postępu cywilizacyjnego wcale nie ułatwia życia, jak się nam wydaje, tylko je utrudnia. Rozum nie jest zatem w stanie rozwiązać samodzielnie żadnego ze społecznych problemów, przeciwnie - może za to je wytwarzać i pogłębiać. Wreszcie rozum zagłuszający głos serca i blokujący siły woli szkodzi nam o wiele bardziej, niż pomaga. Absolutny posłuch okazywany rozumowi jest sprzeczny z naturą, od której nas oddala, sprawiając, że coraz bardziej cierpimy i nigdy nie będziemy w stanie osiągnąć pełni szczęścia. Wymownym przykładem postaci, która, według Rousseau, kierując się właśnie rozumem, swoją postawą szkodziła sobie $\mathrm{i}$ innym, była jego tzw. mamusia, czyli Pani de Warens. Opisana w Wyznaniach, z jednej strony, czyli z natury jako kobieta: ,urocza” i „o czystym sercu”, z drugiej strony, czyli przez wychowanie będąca osobą o „lodowatym temperamencie”, osobą systematyczną, ostrożną i sformalizowaną, która mając do wyboru czy iść za głosem rozumu czy serca, stawiała na rozum, w efekcie czego: ,,...] wszystkie jej zabłąkania wynikały z mylnych zasad, a nie z namiętności. Była szlachetna z natury, serce jej było czyste, lubiła to, co uczciwe, skłonności miała cnotliwe i zacne, smak delikatny; słowem była stworzona do wykwintu moralnego, za którym zawsze tęskniła, a którego nigdy nie znalazła, zamiast bowiem słuchać serca, które ją prowadziło dobrze, słuchała rozumu, który ją prowadził źle. Kiedy fałszywe zasady zagnały ją na manowce, dobre instynkty zawsze stawały im wbrew; ale na nieszczęście miała w głowie ćwieka filozofii, i zasady moralne, które sobie zbudowała, zniszczyły te, które dyktowało jej serce"s2.

Ze zmysłami bowiem człowiek się rodzi, korzystając $\mathrm{z}$ nich w sposób automatyczny: wzrok, słuch, smak, powonienie, dotyk to pierwotne i pierwsze

\footnotetext{
${ }^{49}$ Idem: Emil, czyli..., s. 54.

${ }^{50}$ Ibidem, s. 110.

${ }^{51}$ Ibidem, s. $110-111$.

52 J.J. Rousseau: Wyznania..., s. 237.
} 
źródła poznawcze, w które wyposażyła nie tylko nasz gatunek przyroda. „Istnieję i posiadam zmysły, którymi odbieram wrażenia. Oto pierwsza prawda, która mnie uderza [...]. Nie jestem więc istotą wyłącznie bierną i zmysłową, lecz także czynną i rozumną" ${ }^{33}$. Zmysły są naszymi pierwszymi nauczycielami oraz narzędziami wiadomości i inteligencji, ,ponieważ wszystko, co przenika do pojęcia ludzkiego, przenika tam przez zmysły, przeto pierwsze rozumowanie ludzkie jest rozumowaniem za pomocą zmysłów; ono to jest podstawą rozumowania intelektualnego: pierwszymi nauczycielami filozofii są dla nas nasze nogi, ręce, oczy" 54 . Poza tym należy je ćwiczyć i wychowywać, ,[...] nie znaczy to jedynie używać ich, ale uczyć się z ich pomocą dobrze zdawać sobie sprawę; znaczy to uczyć się, że tak powiem, czuć, umiemy bowiem dotykać, widzieć, słyszeć tak właśnie, jakeśmy się tego nauczyli"55. Oprócz rozwijania umiejętności właściwego używania zmysłów, również z wiekiem powinniśmy dopiero uczyć się korzystania z rozumu. Tak jednak nie robimy i dlatego „ogólny błąd wszystkich rodziców, dumnych ze swej wiedzy - to przypuszczenie, że dzieci są rozsądne od urodzenia, i przemawianie do nich, jak do dorosłych, zanim nawet potrafią mówić. Rozum jest narzędziem, którym chcą się posłużyć przy nauczaniu, podczas gdy właśnie on powinien być kształcony za pomocą innych narzędzi, a ze wszystkich nauk ludziom właściwych tą, którą uzyskuje najpóźniej i najtrudniej, jest sam rozum" ${ }^{\text {"56. }}$.

\section{Konieczność irracjonalizacji życia spolecznego}

Aby w pełni ująć prostotę irracjonalizmu oraz przesłanie stworzonej przez Jana Jakuba Rousseau filozofii, należy uznać za kluczowe trzy szczególnie eksponowane przez niego pojęcia. Stanowią one kwintesencję, a zarazem szczytowe osiągnięcie jego światopoglądu, który zawdzięczał nie tylko własnemu rozwojowi intelektualnemu, ale przede wszystkim nieustannemu rozbudzaniu, a nie zagłuszaniu sfery uczuć i siły woli. Pojęciami tymi, ściśle ze sobą związanymi, są, po pierwsze, umowa społeczna, po drugie: suwerenny lud, po trzecie: wola powszechna. Wszystkie pojęcia pochodzą z tzw. filozofii społecznej Jana Jakuba Rousseau, która stała się dla niego najważniejszym działem filozofii nowożytnej, gdyż wiązała się bezpośrednio $\mathrm{z}$ najpoważniejszymi problemami dotyczącymi życia wszystkich ludzi. Każde z nich ma określone miejsce, swoją kolejność oraz

\footnotetext{
53 Ibidem, s. 92 i 95.

${ }^{54}$ J.J. Rousseau: Emil, czyli..., s. 139.

${ }^{55}$ Ibidem, s. 149.

56 J.J. Rousseau: Nowa Heloiza..., s. 243.
} 
swój teoretyczny i praktyczny cel, którego osiągnięcie jest warunkiem koniecznym rzeczywistej poprawy życia społecznego. $Z$ tych trzech pojęć umowa społeczna jako model teoretyczny a nie historyczny punkt wyjścia jest najbardziej racjonalistyczna. Jej główne założenia są racjonalne i wskazują właśnie na rozum jako źródło procesu cywilizacyjnego, a zarazem postępu. To rozwijający się rozum wyprowadził bowiem ludzkość ze szczęśliwego stanu natury - dokonując naszego uspołecznienia. Umowa społeczna jako koncepcja filozoficzna, a zarazem teoretyczny projekt, jest bardzo przemyślana. Można nawet powiedzieć, że rozum jest nie tylko źródłem umowy społecznej, ale także jej pomysłodawcą. Odpowiada on za właściwe przeprowadzenie człowieka, a zarazem ludzkość ze stanu natury w stan społeczny. To dzięki umowie społecznej i rozumowi człowiek miał stać się obywatelem. Wszystko byłoby wspaniale i nadal żylibyśmy niemal jak w stanie natury, godząc wolność $\mathrm{z}$ równością $\mathrm{w}$ ramach nowych wzajemnych stosunków społecznych o charakterze ekonomicznym, politycznym i prawnym, gdyby ktoś nie wpadł na pomysł: ogrodzenia kawałka ziemi i oznajmienia innym, że odtąd to moje. Tak właśnie pojawiła się pierwsza nierówność społeczna oparta na własności prywatnej, w wyniku której w sensie globalnym garstka bogaczy do dzisiaj w zasadzie pławi się w zbytku, gdy większości ludzi brakuje rzeczy niezbędnych. Od tej pory rozum nie tylko uzasadniał konieczność istnienia nierówności społecznych, ale także pogłębiał je i rozszerzał na inne sfery życia społecznego ludzi ${ }^{57}$. Obok podziału na bogatych i biednych pojawiły się inne nierówności społeczne, w których bogaci stawali się rządzącymi, a biedni poddanymi, by w końcu doprowadzić do najbardziej upodlającej większość ludzi, czyli biednych i poddanych, pozbawionych ostatecznie wolności, a zatem relacji (garstki) panów i (rzeszy) niewolników. Tak jak w pierwszej rozprawie Rousseau wystąpił przeciwko: cywilizacji, postępowi, nauce i kulturze, tak w drugiej Rozprawie o nierównościach społecznych wystąpił przeciwko ustrojowi społecznemu opartemu na tych nierównościach.

W rezultacie Rousseau czynił rozum odpowiedzialnym za całe zło moralne i niesprawiedliwość społeczną tego świata, którą sankcjonował za pomocą stanowionego przez siebie, a niezgodnego z naturą prawa. Na zasadzie logicznej konsekwencji pogłębianie i sankcjonowanie nierówności społecznych zawsze prowadzić ma do zniewolenia człowieka przez człowieka ${ }^{58}$. Niestety rozum umiejętnie wykorzystywany przez nielicznych czynił to w sposób zaplanowany i na tyle skuteczny, że potrafił zagłuszyć nie tylko głos rozpaczy indywidualnych serc ludzkich, ale także zniweczyć zbiorową siłę ludu drzemiącą w postaci jego suwerenności, nie dopuszczając przy tym do wyrażenia przez niego woli.

${ }^{57}$ Zob. K. Kuźmicz: Nierówności społeczne w państwie wedtug Jana Jakuba Rousseau jako zaprzeczenie godności ludzkiej. W: Podstawy materialne państwa. Zagadnienia prawno-historyczne. Red. D. Bogacz, M. Tkaczuka. Szczecin 2006.

${ }_{58}$ Por. R. Spaemann: Rousseau - człowiek czy obywatel. Dylemat nowożytności. Przeł. J. Marecki. Warszawa 2011, s. 131. 
Według Rousseau cała ludzkość składa się w zasadzie z ludu, a to, co nie jest ludem, jest tak nieliczne, że nie wchodzi (dla niego) w rachubę ${ }^{59}$. Będąc suwerenem - lud stanowi zbiorową formę ludzi uspołecznionych jako równych i wolnych obywateli, kierujących się przede wszystkim emocjami. Rozum ludzki w postaci intelektu jest zawsze zindywidualizowany, zaś prawdziwa siła emocji, które także dotyczą jednostek, przejawia się w oddziaływaniu na masy społeczne. Suwerenny lud jest taką właśnie masą, która gdyby targana była jedynie emocjami, nie wyraziłaby nigdy swojej woli. A jednak dzięki swojej wewnętrznej intuicji tylko i wyłącznie suwerenny lud jest w stanie ją wyrazić, wtedy gdy jego uczucia ustąpią miejsca innej irracjonalnej, a zarazem największej i najważniejszej dla Rousseau sile - powszechnej woli. W związku z tym, bez umowy społecznej, lud nie zostałby suwerenem, a bez suwerennego ludu wola powszechna nie nabrałaby mocy prawodawczej i nigdy nie zostałaby wyrażona. Co ciekawe, Rousseau obydwoma terminami (fr. souverainté i fr. volonté général) posługiwał się na przemian, nie dbając o ich ścisłość i często używając w tym samym znaczeniu ${ }^{60}$. W tym kontekście idea tej ostatniej jest szczytowym osiągnięciem filozofii Rousseau, stanowiąc przejaw obywatelskiej suwerenności ${ }^{61}$, a także gwarancję naszej niewinności jako ludzi i jako obywateli ${ }^{62}$.

Umowa społeczna $\rightarrow$ suwerenny lud $\rightarrow$ wola powszechna $($ racjonalizm $) \rightarrow$ (intuicjonizm) $\rightarrow$ (woluntaryzm)

Ta ostatnia, ujmowana w sensie moralnym jako kwintesencja najwyższego dobra, jest także: powszechna, nieomylna, niezmienna, niezbywalna, wieczna, sprawiedliwa, a zatem doskonała. Wola powszechna zawsze pozostaje w zgodzie z prawem natury, przez co staje się najwyższym prawem. Wola, którą obdarzyła każdego człowieka natura, jest wolna, dzięki czemu stanowi najpierwotniejsze źródło wszelkiego czynu, a zatem także i naszej moralności, której nie byłoby bez możliwości dokonywania wyborów ${ }^{63}$. Swoją koncepcję woli Rousseau ściśle wiąże z wolnością jako najwyższą etyczną wartością oraz Opatrznością. Według niego: „skoro człowiek jest wolny w swoich czynach, może on postępować samodzielnie. Wszystko, co czyni on z własnej woli, nie wchodzi w zakres systemu rządzonego przez Opatrzność, nie może więc być zapisana na Jej rachunek. Opatrzność nie chce zła, które czyni człowiek, nadużywając danej mu wolności, lecz też i nie powstrzymuje go [...]. Opatrzność stworzyła człowieka wolnym, by czynił nie zło, lecz dobro z własnego wy-

59 J.J. Rousseau: Emil, czyli..., s. 26.

${ }^{60}$ Por. A. Peretiatkowicz: Jan Jakub Rousseau filozof demokracji spotecznej. Poznań 1949, s. 211.

${ }^{61}$ R.A. Tokarczyk: Filozofia prawa w perspektywie prawa natury. Białystok 1996, s. 104.

${ }^{62}$ I. Barwicka-Tylek: Portrety wolności. Studium z historii idei i postmodernizmu ,,stosowanego". Kraków 2009, s. 136.

${ }^{63}$ Por. J.J. Rousseau: Emil, czyli..., s. 109. 
boru" ${ }^{64}$. Jak widać, wola ma przy tym charakter jednostkowy, jak również powszechny. Powszechność jej polega na wiedzy i potędze, dzięki której wola rządzi światem ${ }^{65}$. Wierzy $\mathrm{w}$ nią, że porusza świat i ożywia przyrodę, uznaje za dogmat, który ma jednak sens nierażący przy tym rozumu ani doświadczenia ${ }^{66}$. Antoni Peretiatkowicz wskazywał na wolę powszechną u Rousseau, po pierwsze, jako centralną oś całej jego filozoficznej konstrukcji; po drugie, jako warunek zasadniczy koncepcji umowy społecznej i po trzecie, jako punkt wyjścia jego poglądów o charakterze normatywnym ${ }^{67}$. W ten sposób wola powszechna w każdej jednostce ludzkiej będącej częścią suwerennego ludu, staje się „,czystym aktem rozumu, który wśród ciszy namiętności rozważa, czego człowiek może wymagać od bliźniego i czego bliźni mają prawo od niego wymagać" ${ }^{68}$.

\section{Podsumowanie}

Faktem dla Rousseau stało się to, że osamotniony i zdany sam na siebie rozum zawiódł oraz wszystko, co na nim się bezkrytycznie opierało, a w szczególności stosunki międzyludzkie, w tym życie ekonomiczne, polityczne, prawne, religijne i kulturowe. Zaproponowane na te wszystkie problemy rozwiązanie, ma, jak to u Jana Jakuba Rousseau bywa, charakter paradoksalny. To właśnie na odpowiedzialnym za to wszystko rozumie spoczywa jednak pewien imperatywny obowiązek. Jaki to obowiązek? Opamiętania się poprzez ustąpienie miejsca porządkowi serca $\mathrm{w}$ relacjach moralnych między ludźmi, a w relacjach politycznych podporządkowania się i służbie decyzjom podejmowanym przez suwerena, czyli lud wyrażający wolę powszechną. Rozum nie ma jednak prawa dokonać tego wbrew sobie, lecz zgodnie ze swoją naturalną skłonnością do autorefleksji o charakterze krytycznym, doprowadzając do tego, czego wymaga na początku każda racjonalna metoda (w tym sokratejska i kartezjańska), czyli pokory prowadzącej do uświadomienia swoich ograniczonych zdolności nie tylko w zakresie poznawania świata, ale przede wszystkim w sposobie jego wartościowania i kreowania. Oceniając system stworzony przez Jana Jakuba Rousseau, dojdzie się w końcu do następującego wniosku, że był on z pewnością najsłynniejszym

${ }^{64}$ Ibidem.

${ }^{65}$ Powyższe rozważania prowadzą Jana Jakuba Rousseau do sformułowania własnych zasad wiary w Istotę Najwyższą — zwaną Bogiem, „istniejącą samą w sobie i samą przez się”, utożsamianą z Mądrością i Opatrznością oraz pojęciami: Rozumu, Siły i Woli, jako też Dobroci — nieuniknionej konsekwencji trzech pierwszych.

${ }_{66}^{6}$ J.J. Rousseau: Emil, czyli..., s. 98 i 99.

${ }^{67}$ Por. A. Peretiatkowicz: Jan Jakub Rousseau filozof..., s. 169 i nast.

${ }^{68}$ J.J. Rousseau: Umowa spoteczna..., s. 173-174. 
oświeceniowym irracjonalistą, ale na pewno nie antyracjonalistą. Dlatego słuszne wydaje się określenie jego światopoglądu mianem irracjonalizmu buntowniczego.

Sam bowiem Rousseau podaje najlepszy i najprostszy, a zarazem bardzo skuteczny sposób budowania lepszego świata, ale wymagający od nas w pierwszej kolejności rzeczy najważniejszej: bycia prawdziwym człowiekiem ${ }^{69}$. Pisał o tym w swoim traktacie o wychowaniu, zwracając się bezpośrednio do tytułowego Emila: „Pamiętaj, że zanim odważysz się przedsięwziąć formowanie człowieka, musisz przedtem sam stać się człowiekiem; musisz z samego siebie uczynić przykład [...]. Trzeba poświęcić bliźnim swój czas, starania, życzliwość, siebie samego [...]. Doprowadzaj do zgody ludzi, którzy się na siebie gniewają; usuwaj przyczyny zatargu; przypominaj dzieciom obowiązki, ojcom pobłażliwość; dopomagaj do szczęśliwych małżeństw; przeszkadzaj zadrażnieniom [...]. Stawaj otwarcie i śmiało w obronie nieszczęśliwych. Bądź sprawiedliwy, ludzki, dobroczynny. Nie dawaj jedynie jałmużny — świadcz dobroczynność; dzieła miłosierdzia leczą więcej cierpień niż pieniądz: kochaj bliźnich, a oni również kochać cię będą; służ im, a będą ci służyli; bądź im bratem, a będą twymi dziećmi"70.

$\mathrm{Z}$ całą pewnością możemy uznać przynajmniej niektóre propozycje Rousseau za utopię społeczną, zbyt jednak doskonałą dla rodzaju ludzkiego ${ }^{71}$. Ale nawet jeśli tak by było, to warto próbować ją realizować w jednym i najważniejszym celu: aby zobaczyć wszystkie serca zadowolone, bowiem już sam widok powszechnej szczęśliwości potrafiłby zapewnić sercu trwałe wzruszenie, a gorące pragnienie czuwania nad jej zachowaniem byłoby najbardziej trwałą dążnością ${ }^{72}$. Dlatego prawdziwa wartość człowieka znajduje się w jego sercu, a nie rozumie - i to jest najważniejsze przesłanie Jana Jakuba Rousseau ${ }^{73}$. Myśliciela, który głosił filozofię uczucia w praktyce a nie tylko w teorii ${ }^{74}$. W ten sposób Rousseau uczy nas ludzi pełni człowieczeństwa.

\section{Bibliografia}

Baczko B.: Paradoksy russoistyczne. Wstep do dziet wybranych J.J. Rousseau. Warszawa 1966.

Baczko B.: Rousseau: samotność i wspólnota. Warszawa 1964.

${ }^{69}$ Por. M.-V. Howlett: Jean-Jacques Rousseau: l'homme qui croyait en l'homme. Paris 1989.

${ }^{70}$ J.J. Rousseau: Emil, czyli..., s. 92 i 93.

${ }^{71}$ Por. M. Blaszke: Umowa spoteczna..., s. 72.

72 Por. J.J. Rousseau: Marzenia..., s. 88.

${ }^{73}$ Por. W. Tatarkiewicz: Historia filozofii..., s. 152-153.

${ }^{74}$ Por. J. Maritain: Trzej reformatorzy: Luter, Kartezjusz, Rousseau. Tłum. K. Michalski. Warszawa 2005, s. 138. 
Barwicka-Tylek I.: Portrety wolności. Studium z historii idei i postmodernizmu „stosowanego". Kraków 2009.

Baszkiew icz J., Rys zk a F.: Historia doktryn politycznych i prawnych. Warszawa 1979.

Blaszke M.: Umowa społeczna J.J. Rousseau — polityka i racjonalność. „Archiwum

Historii Filozofii i Myśli Społecznej” 1987, T. 32.

Burda A.: Metoda i ogólny charakter doktryny politycznej J.J. Rousseau. Lublin 1954.

Carlyle T.: Bohaterowie, cześć dla bohaterów i pierwiastek bohaterstwa $w$ historii:

Odyn, Mahomet, Dante, Szekspir, Luter, Knox, Johnson, Rousseau, Cromwell, Napoleon. Warszawa 2010.

Dąbrowski K.: Dezintegracja pozytywna. Warszawa 1979.

Derathé R.: Le Rationalisme de Jean-Jacques Rousseau. Paris 1979.

Feuchtwanger L.: Mąrość glupca albo śmierć i apoteoza Jana Jakuba Rousseau. Tłum. J. Frühling. Warszawa 1959.

Howlett M.-V.: Jean-Jacques Rousseau: l'homme qui croyait en l'homme. Paris 1989.

Kant I.: Krytyka czystego rozumu. Tłum. R. Ingarden. T. 2. Warszawa 1957.

Kuźmicz K.: Nierówności społeczne w państwie wedtug Jana Jakuba Rousseau jako zaprzeczenie godności ludzkiej. W: Podstawy materialne państwa. Zagadnienia prawno-historyczne. Red. D. Bogacz, M. Tkaczuka. Szczecin 2006.

Kuźmicz K.: Transhumanizm. W: Edukacja na rozdrożu. Red. M. Szyszkowska. Białystok 2015.

Maritain J.: Trzej reformatorzy: Luter, Kartezjusz, Rousseau. Tłum. K. Michalski. Warszawa 2005.

Morawiecki J.: Strach zabija róże. „Polityka” 1998, nr 39.

Orłowski B.: Krytyka wartości kultury u Rousseau i przed Rousseau'em. Ze studjów nad geneza i znaczeniem rozpraw konkursowych Jana Jakóba Rousseau. Poznań 1921.

Peretiatkowicz A.: Jan Jakub Rousseau filozof demokracji społecznej. Poznań 1949.

Rousseau J.J.: Emil czyli o wychowaniu I. Przeł. W. Husarski. Wrocław 1955.

Rousseau J.J.: Marzenia samotnego wędrowca. Wrocław 1983.

Rousseau J.J.: Nowa Heloiza. Tłum. E. Rzadkowska. Warszawa 1995.

Rousseau J.J.: Rozprawa o naukach i sztukach. W: Idem: Trzy rozprawy z filozofii społecznej. Przekł. H. Elzenberg. Wrocław-Warszawa-Kraków 1956.

Rousseau J.J.: Szkic o pochodzeniu języków. Przeł. B. Banasiak. Kraków 2001.

Rousseau J.J.: Umowa społeczna. Przeł. A. Peretiatkowicz. Warszawa 1966.

Rousseau J.J.: Uwagi o rządzie polskim. Tłum. B. Baczko. Warszawa 1966.

Rousseau J.J.: Wybór tekstów pedagogicznych. Oprac. H. Pohoska. Warszawa 1949. Rousseau J.J.: Wyznania I. Przeł. T. Żeleński (Boy). Warszawa 1978.

Spaemann R.: Rousseau - człowiek czy obywatel? Dylemat nowożytności. Przeł. J. Merecki. Warszawa 2011.

Starobinski J.: Jean-Jacques Rousseau. Przejrzystość i przeszkoda oraz siedem esejów o Rousseau. Przeł. J. Wojcieszak. Warszawa 2000.

Suchodolski B.: Rozwój nowożytnej filozofii człowieka. Warszawa 1967.

Święczkowska H.: Pochodzenie języka wedtug Jana Jakuba Rousseau: kilka uwag na marginesie przekładu polskiego. „Idea. Studia nad rozwojem i strukturą pojęć filozoficznych" 2003, T. 15.

Tatarkiewicz W.: Historia filozofii. T. 2: Filozofia nowożytna do roku 1830. Warszawa 1990. 
Tokarczyk R.A.: Filozofia prawa w perspektywie prawa natury. Białystok 1996. Waśkiewicz A.: Obcy z wyboru. Studium filozofii aspołecznej. Warszawa 2008. Zmierczak M.: Jan Jakub Rousseau - rzecznik totalitaryzmu czy liberalnej demokracji?. „Czasopismo Prawno-Historyczne” 1989, T. 41, z. 2.

\section{Jean-Jacques Rousseau - ein irrationaler Rebell}

Schlüsselwörter: Bildung, Irrationalismus, Rückkehr zur Natur, allgemeiner Wille

Zusammenfassung: Jean-Jacques Rousseau ist vor allem ein Sozialphilosoph. Seine Theorie des Gesellschaftsvertrages, Theorie der Volkssouveränität und des allgemeinen Willens sind die Grundbegriffe sowohl in der Rechtsphilosophie als auch im politischen und wirtschaftlichen Denkens. Obwohl Rousseau mit der Epoche der Aufklärung verbunden war, in der die Errungenschaften der auf dem Verstand und dem Experimentieren beruhenden Wissenschaften gewürdigt wurden, trat er als Denker auf, der es versuchte, diesen Sachverhalt in Frage zu stellen. Seit Beginn seines Schaffens baut er ein Weltbild auf, das wir als Ausdruck des Protestes gegen die unkritische Dominanz des Rationalen betrachten können. Er ist mit der bisherigen Verneinung irrationaler Faktoren nicht einverstanden, denen laut ihm gebührende Aufmerksamkeit geschenkt werden sollte, sowohl im Erziehungsprozess des Individuums als auch auf gesellschaftspolitischer Ebene. Er betrachtet die richtige Entwicklung der emotional-gewollten Sphäre als die beste Medizin, die dazu beitragen kann, alle Probleme im Leben der Menschen zu lösen, mit denen unser Intellekt nicht fertig werden kann.

Karol Kuźmicz

\section{Jean-Jacques Rousseau — an irrational rebel}

Keywords: education, irrationalism, return to nature, general will

Summary: Jean-Jacques Rousseau is primarily a social philosopher. His theories of a social contract, of sovereignty of the people, and of general will are basic concepts in the philosophy of law and political and economic thought. Although associated with the Enlightenment as an epoch in which the achievements of the sciences based on reason and experiment were paid tribute, Rousseau appeared as a thinker trying to undermine this fact. From the very beginning of his work, he has been building a worldview that can be seen as a manifestation of rebellion against the uncritical domination of the rational. He does not accept the negation of irrational factors, to which he proposes to give their rightful place, both in the individual's educational process, and on the social and political level. He considers the proper development of the emotional and volitive sphere to be the best medicine that can help solve all the problems of life of people with which our intellect is unable to cope. 